\title{
Activated carbons from common nettle as potential adsorbents for $\mathrm{CO}_{2}$ capture
}

\author{
Alicja Szymańska*, Amelia Skoczek, Jacek Przepiórski \\ West Pomeranian University of Technology, Szczecin, Faculty of Chemical Technology and Engineering, Institute of Inor- \\ ganic Chemical Technology and Environment Engineering, Piastów Ave. 42, 71-065 Szczecin, Poland \\ *Corresponding author: e-mail: alicja.szymanska@zut.edu.pl
}

\begin{abstract}
Activated carbons (ACs) prepared from common nettle (Urtica Dioica L.) were studied in terms of carbon dioxide adsorption. ACs were prepared by $\mathrm{KOH}$ chemical activation in a nitrogen atmosphere at temperatures (ranging from 500 to $850^{\circ} \mathrm{C}$ ). The pore structure and the surface characterization of the ACs were specified based on adsorption-desorption isotherms of nitrogen measured at $-196^{\circ} \mathrm{C}$ and carbon dioxide at $0^{\circ} \mathrm{C}$. The specific surface area was calculated according to the BET equation. The pore volume was estimated using the DFT method. The highest values of the specific surface area (SSA) showed activated carbons produced at higher carbonization temperatures. All samples revealed presence of micropores and mesopores with a diameter range of 0.3-10 nm. The highest value of the $\mathrm{CO}_{2}$ adsorption, $4.22 \mathrm{mmol} / \mathrm{g}$, was found for the material activated at $700^{\circ} \mathrm{C}$.
\end{abstract}

Keywords: activated carbon, common nettle, $\mathrm{CO}_{2}$ adsorption, chemical activation.

\section{INTRODUCTION}

Earth's climate is seriously affected by the greenhouse effect of water vapor and clouds, carbon dioxide, methane and other gases. In the context of energy utilization and green house gases (GHG) emissions, $\mathrm{CH}_{4}$ and $\mathrm{CO}_{2}$ are of main significance. Carbon dioxide is the main contributor, mainly from the utilization of fossil fuels in combustion applications for energy conversion. Nowadays, there are an environmental regulations and requirements to impose the control of the accumulation of $\mathrm{CO}_{2}$ and $\mathrm{CH}_{4}$ in the atmosphere.

Methane - the main component of natural gas is mostly used as a fuel. During combustion, this valuable raw material is converted to carbon dioxide. Apart from this, methane is converted to other required by an industry raw materials and fuels via the well-known steam reforming technology, firstly converting it to synthesis gas $^{1,2}$. The syngas is used for production of methanol and its derivatives e.g. methyl tert-butyl ether (MTBE), formaldehyde, and acetic acid ${ }^{3}$. Hydrogen from syngas is used such processes like hydrocracking, hydrodesulfurization, or ammonia synthesis ${ }^{4,5}$. This indirect method needs significant energy consumption and is expensive because the steam reforming reaction of methane is highly endothermic ${ }^{6}$.

The other methods for synthesis gas production, dry reforming ${ }^{1}$ and partial oxidation ${ }^{7}$, have limitations. The dry reforming reaction is also endothermic, but the advantage of this method is the equimolar formation of $\mathrm{CO}_{2}$ and $\mathrm{H}_{2}$. The partial oxidation of methane is an exothermic process and it requires either oxygen or air as oxidizing agent. During the process, methane is converted to $\mathrm{CO}_{2}$.

Direct conversion of methane is a promising alternative for the production of value-added products ${ }^{8}$. Synthesis of methanol ${ }^{9-11}$ and formaldehyde ${ }^{8-13}$, oxidative coupling of methane $\mathrm{e}^{14}$ and conversion to aromatics ${ }^{15}$ without an oxidant, can be considered as direct conversion ways of methane. The interesting method of methane esterification in the oleum to methyl bisulphate was also studied and described ${ }^{16-22}$ in the literature. The methyl bisulphate can be easily hydrolyzed to methanol ${ }^{22-28}$. The catalytic decomposition of methane was also investigated in details ${ }^{29-36}$. Apart from hydrogen, formation of both carbon nanotubes ${ }^{29-35}$ and nanocapsule ${ }^{36}$ was confirmed as taking place during this process. The methods avoiding the syngas production are superior to indirect methods with respect to the economic issues. However, so far no direct way has been put into practice due to low yields of the desired products ${ }^{37}$.

The most widely studied technology limiting $\mathrm{CO}_{2}$ emission is the Carbon Capture and Sequestration (CCS). The method consists of $\mathrm{CO}_{2}$ capture from a flue gas, transportation and underground storage. The most common $\mathrm{CO}_{2}$ conversion to the value-added product is urea production. The attempts of $\mathrm{CO}_{2}$ conversion to other products such as methane and methanol via photocatalytic reduction were described as well ${ }^{38-41}$.

Nowadays, conventionally used in industrial practice $\mathrm{CO}_{2}$ arresting methods - using water monoethanolamine based solvent systems, are too expensive for CCS. An alternative to the above process is sorption using solid sorbent materials. These sorbents are considered as promising because they reveal high $\mathrm{CO}_{2}$ uptakes and low heat capacities. Compared to the liquid solvent systems, solid sorbents are less corrosive, and toxicity and do not have volatility issues associated with liquids.

A number of studies indicate that solid sorbents have the potential of using 2 to 2.5 times less energy for regeneration than aqueous phase scrubbing ${ }^{42,43}$.

A lot of materials have been proposed and developed for $\mathrm{CO}_{2}$ capture from flue gas. Mainly carbonaceous materials including: activated carbons ${ }^{44-50}$, multiwalled carbon nanotubes ${ }^{51}$, carbon nanosheets ${ }^{52}$, activated carbon fibers ${ }^{53}$, carbon spheres ${ }^{54}$, zeolites $^{56,56}$, and metal-organic frameworks ${ }^{57,58}$, were studied as $\mathrm{CO}_{2}$ sorbents. Beside these, various other materials like $\mathrm{TiO}_{2}{ }^{59-61}$ or $\mathrm{MgO}^{62}$, were tested as potential $\mathrm{CO}_{2}$ sorbents.

The $\mathrm{CO}_{2}$ adsorption on zeolites is strongly affected by the presence of water vapour. For that reason, the use of zeolites in regenerative processes requires extra facilities for thorough dehydration of flue gases prior $\mathrm{CO}_{2}$ sorption. This necessity makes this solution more expensive ${ }^{63}$. The price of metal-organic frameworks 
production is still high ${ }^{64}$. Therefore, the carbonaceous materials, particularly activated carbons, are considered as the best potential $\mathrm{CO}_{2}$ sorbents, ${ }^{4,49}$.

Activated carbons have typically high surface area ${ }^{\mathbf{6 5 , 6 6}}$, pore volume $\mathrm{e}^{67,68}$, especially micropore volume ${ }^{69,70}$. These features are of key importance for $\mathrm{CO}_{2}$ adsorption ${ }^{49}$ and also for $\mathrm{CH}_{4}{ }^{71-73}$ and $\mathrm{H}_{2}$ storage $74^{74-79}$. Activated carbons find many different applications from filtration to purification and beyond. They are also used as catalysts ${ }^{80-82}$ or catalysts supports ${ }^{83-85}$.

Activated carbon can be produced from raw materials of different origin, including wood, coals, and also biomass containing wastes originating from animals, minerals and vegetables ${ }^{86-91}$. The choice of raw material depends basically on price, purity, potential extent of activation, stability and supply ${ }^{92}$. The type of starting material or precursor has a strong impact on plays the quality, characteristics and properties of the resulting activated carbons.

In the current literature, there is no work regarding the activated carbons prepared from nettle. The objective of this study is to use the waste of nettles infusion as the raw material to prepare the activated carbons using $\mathrm{KOH}$ as the activating agent, and to define the effect of carbonization temperature on the properties of the final product, especially in relation to the $\mathrm{CO}_{2}$ adsorption.

\section{EXPERIMENTAL}

\section{Preparation of activated carbons}

Dry common nettle $(\mathrm{CN})$ was ground and treated with a saturated solution of potassium hydroxide $(\mathrm{KOH})$, which was an activating agent. The mass ratio calculated for dry biomass to $\mathrm{KOH}$ was equal to $1: 1$. Portions of the mixtures were left for $3 \mathrm{~h}$ at $25^{\circ} \mathrm{C}$ and atmospheric pressure. Afterward, obtained impregnated samples were dried for $19 \mathrm{~h}$ at $200^{\circ} \mathrm{C}$ and carbonized at temperatures from $500^{\circ} \mathrm{C}$ to $850^{\circ} \mathrm{C}$ (step $50^{\circ} \mathrm{C}$ ) for $1 \mathrm{~h}$ under the nitrogen flow of $18 \mathrm{dm}^{3} / \mathrm{min}$. After cooling down, the activating agent was removed from the products by mean of washing with distilled water, and subsequent soaking in hydrochloric acid $\left(1 \mathrm{~mol} / \mathrm{dm}^{3}\right)$ for $19 \mathrm{~h}$, and final washing with distilled water until $\mathrm{pH}$ of the filtrate became 7. Washed ACs were dried for $19 \mathrm{~h}$ at $200^{\circ} \mathrm{C}$ and then powdered.

\section{Characterization of activated carbons}

The textural characterization of ACs was based on physical adsorption-desorption isotherms measured at the boiling point of liquid nitrogen $\left(-196^{\circ} \mathrm{C}\right)$ using the automated adsorption system Quadrasorb (Quantachrome Instruments). Before the analysis, all samples were degassed under vacuum at $200^{\circ} \mathrm{C}$ for at least $16 \mathrm{~h}$. The specific surface area (SSA) was calculated from $\mathrm{N}_{2}$ isotherms using the multipoint Brunauer-Emmett-Teller $(\mathrm{BET})$ equation. The volumes of micropores $\left(\mathrm{MPV}_{\mathrm{N} 2}\right.$, $\mathrm{MPV}_{\mathrm{CO} 2}$ ) was calculated using the Density Functional Theory (DFT) method on the basis on nitrogen and carbon dioxide adsorption. The total pore volume (TPV) was estimated on the basis of $\mathrm{N}_{2}$ adsorption volume at the relative pressure $\mathrm{p} / \mathrm{p}_{0} \approx 1$. The DFT was also used to establish the pore size distributions (PSD) from sorption isotherms of nitrogen at $-196^{\circ} \mathrm{C}\left(\mathrm{PSD}_{\mathrm{N} 2}\right)$ and carbon dioxide at $0^{\circ} \mathrm{C}\left(\mathrm{PSD}_{\mathrm{CO} 2}\right)$.

Carbon dioxide uptake measurements were carried out at $0^{\circ} \mathrm{C}$ by using the same automated adsorption system as for $\mathrm{N}_{2}$ sorption measurements. In the case, prior to experiments, samples were degassed at $250^{\circ} \mathrm{C}$ under vacuum at $200^{\circ} \mathrm{C}$ for at least $16 \mathrm{~h}$.

A scanning electron microscopy was used to determine the morphology of obtained ACs. The microscope SU8020 (Hitachi) with accelerating voltage of about 15 $\mathrm{kV}$ at 5000x magnification recorded scanning electron micrographs. Samples were spread thinly onto a doublesided carbon adhesive tape glued to an aluminum stub and then inserted to the microscope chamber.

\section{RESULTS AND DISCUSSION}

Figure 1. presents nitrogen adsorption-desorption isotherms of obtained ACs. Isotherms for ACs carbonized at temperatures of $500-750^{\circ} \mathrm{C}$ can be classified as type I(a) for materials CN500, CN550, CN600, CN650 and type I(b) for materials CN700, CN750, according to the IUPAC classification ${ }^{93}$. These types of isotherms indicates a well-developed microporous structure. In the case of materials carbonized at temperatures of $800^{\circ} \mathrm{C}$ and $850^{\circ} \mathrm{C}$ attained isotherms are combinations of type $\mathrm{I}(\mathrm{b})$ and IV(a) ones, i.e., materials reveal contents of both micropores (in predominance) and mesopores. Isotherms measured for materials signed as CN750, CN800,

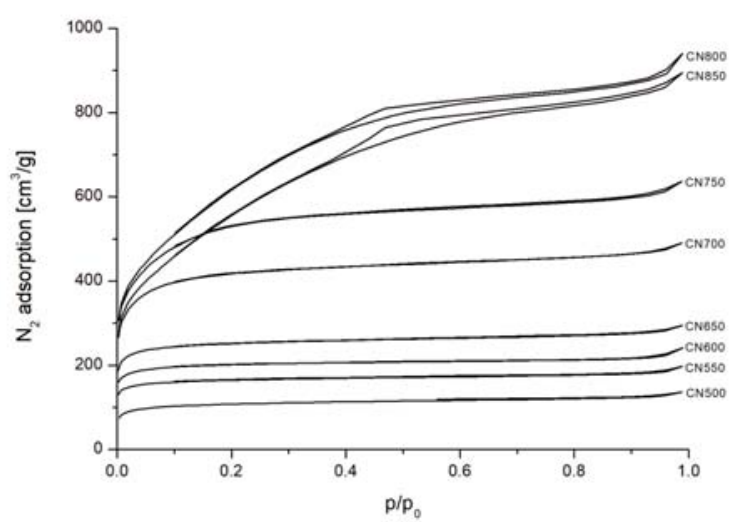

Figure 1. Nitrogen adsorption-desorption isotherms for obtained ACs

Table 1. Textural properties of activated carbons

\begin{tabular}{|l|c|c|c|c|}
\hline Sample & $\mathrm{SSA}\left[\mathrm{m}^{2} / \mathrm{g}\right]$ & $\mathrm{MPV}_{\mathrm{CO} 2}\left[\mathrm{~cm}^{3} / \mathrm{g}\right]$ & $\mathrm{MPV}_{\mathrm{N2}}\left[\mathrm{cm}^{3} / \mathrm{g}\right]$ & $\mathrm{TPV}\left[\mathrm{cm}^{3} / \mathrm{g}\right]$ \\
\hline CN500 & 411 & 0.117 & 0.147 & 0.211 \\
\hline CN550 & 648 & 0.168 & 0.227 & 0.306 \\
\hline CN600 & 793 & 0.193 & 0.279 & 0.375 \\
\hline CN650 & 986 & 0.239 & 0.345 & 0.457 \\
\hline CN700 & 1581 & 0.362 & 0.483 & 0.761 \\
\hline CN750 & 1946 & 0.357 & 0.538 & 0.987 \\
\hline CN800 & 2225 & 0.324 & 0.381 & 1.458 \\
\hline CN850 & 1972 & 0.219 & 0.316 & 1.388 \\
\hline
\end{tabular}


and $\mathrm{CN} 850$ are demonstrate $\mathrm{H} 4$ type hysteresis loops at the relative pressures above 0.3 . Branches of hysteresis are almost horizontal and parallel over a wide range of relative pressures. Type $\mathrm{H} 4$ loops are associating with a presence of narrow slit-like pores ${ }^{\mathbf{9 3 , 9 4}}$.

The textural properties of obtained activated carbons: $\mathrm{SSA}, \mathrm{MPV}_{\mathrm{CO} 2}, \mathrm{MPV}_{\mathrm{N} 2}$, and TPV, are listed in Table 1. The specific surface area values of the prepared materials ranges from 411 to $2225 \mathrm{~m}^{2} / \mathrm{g}$. The specific surface area of ACs increased with a rise of carbonization temperature $\left(500-800^{\circ} \mathrm{C}\right)$. The highest SSA value was found for sample carbonized at $800^{\circ} \mathrm{C}$. In the case of the sample carbonized at $850^{\circ} \mathrm{C}$, the SSA decreased. This effect can be explained by the partial destroying of the porous structure due to impact of high temperature of the process. Values of $\mathrm{MPV}_{\mathrm{CO} 2}, \mathrm{MPV}_{\mathrm{N} 2}$ and TPV were in the range $0.117-0.362 \mathrm{~cm}^{3} / \mathrm{g}, 0.147-0.538 \mathrm{~cm}^{3} / \mathrm{g}$ and $0.211-1.458 \mathrm{~cm}^{3} / \mathrm{g}$. The highest value of TPV was calculated for sample carbonized at $800^{\circ} \mathrm{C}$. The highest value of $\mathrm{MPV}_{\mathrm{N} 2}$ was found for sample carbonized at $750^{\circ} \mathrm{C}$. The value of $\mathrm{MPV}_{\mathrm{CO} 2}$ was comparable for all the ACs studied in this work.

Fig. 2. shows the PSD of activated carbons determined from $\mathrm{CO}_{2}$ adsorption results at $0^{\circ} \mathrm{C}\left(\mathrm{PSD}_{\mathrm{CO} 2}\right)$ and Fig 3. shows the PSD using $\mathrm{N}_{2}$ adsorption results at $-196^{\circ} \mathrm{C}$ $\left(\mathrm{PSD}_{\mathrm{N} 2}\right)$. Both PSDs were calculated by the DFT method. The DFT method based on the $\mathrm{N}_{2}$ adsorption is used to determine the PSD for pores larger than $1 \mathrm{~nm}$, while the DFT method based on the $\mathrm{CO}_{2}$ adsorption is required to determine the PSD for smaller pores ${ }^{95}$. All the samples exhibited contents of pores with a diameter range of $0.3-10 \mathrm{~nm}$. For all the obtained materials, three particularly intense peaks can be observed (Fig. 2.) for diameters of ca. $0.3-0.4 \mathrm{~nm}, 0.4-0.7 \mathrm{~nm}, 0.7-1 \mathrm{~nm}$. The largest volume was occupied by pores with diameters ranging from 0.4 to $0.7 \mathrm{~nm}$ and the presence of pores of diameter range from 0.3 to $0.9 \mathrm{~nm}$, confirms the development of microporosity in the ACs developed.

As can be seen on Fig. 3., the pore volume tends to gradually decrease with the pore diameter. It confirms dominant content of smaller pores in examined mate-
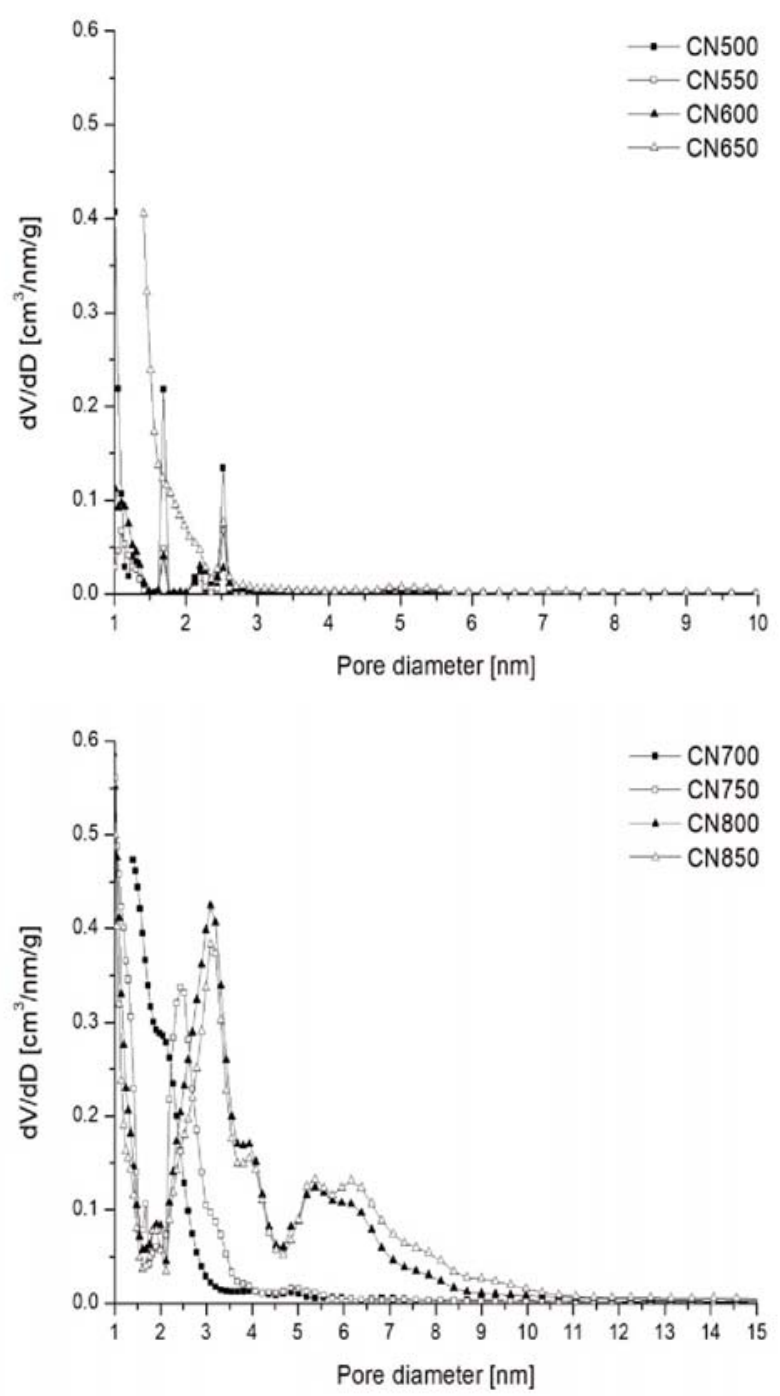

Figure 3. The pore size distributions of ACs calculated from $\mathrm{N}_{2}$ adsorption isotherms ( $\mathrm{D}-$ pores diameter)

rials. The content of pores in the diameter range of $1-10 \mathrm{~nm}$ tends to increase with the grow of carbonization temperature.
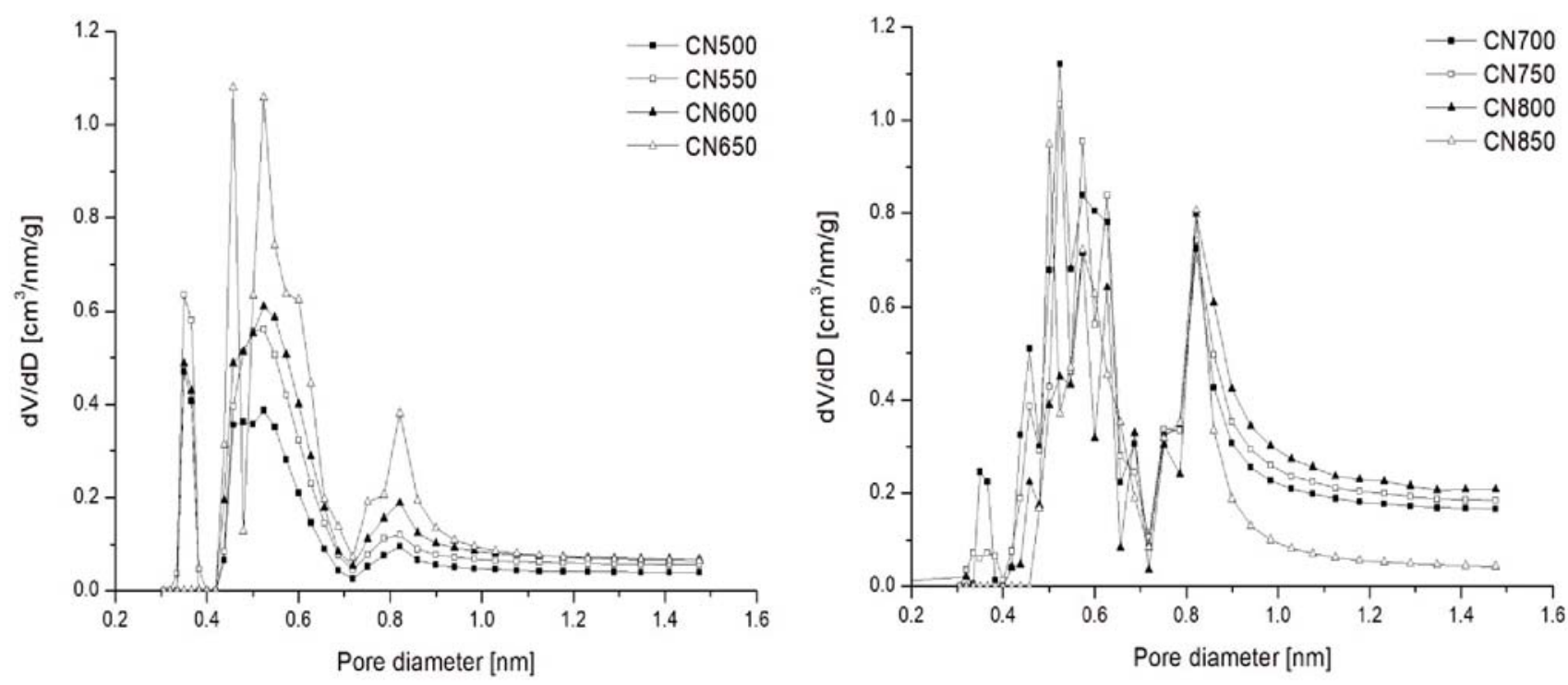

Figure 2. The pore size distributions of $\mathrm{ACs}$ calculated from $\mathrm{CO}_{2}$ adsorption isotherms (D - pores diameter) 
Figure 4. displays carbon dioxide adsorption isotherms measured at $0^{\circ} \mathrm{C}$. Presser et al. ${ }^{96}$ measuring $\mathrm{CO}_{2}$ adsorption isotherms confirmed that at 1 bar pores smaller than $0.8 \mathrm{~nm}$ in diameter contribute the most to $\mathrm{CO}_{2}$ uptake. Figure 4. shows a significant increase in the $\mathrm{CO}_{2}$ adsorption at low pressures and a gradual increase at higher pressures. The adsorption of $\mathrm{CO}_{2}$ increases with the carbonization temperature up to $700^{\circ} \mathrm{C}$. Materials carbonized at higher temperatures were characterized by lower $\mathrm{CO}_{2}$ uptake compared to the others. It is well known that the ACs surface functional groups undergo thermal decomposition, typically at temperatures above $700^{\circ} \mathrm{C}$. The highest value of $\mathrm{CO}_{2}$ capacity, $4.22 \mathrm{~mol} / \mathrm{g}$, was confirmed for CN700 material.

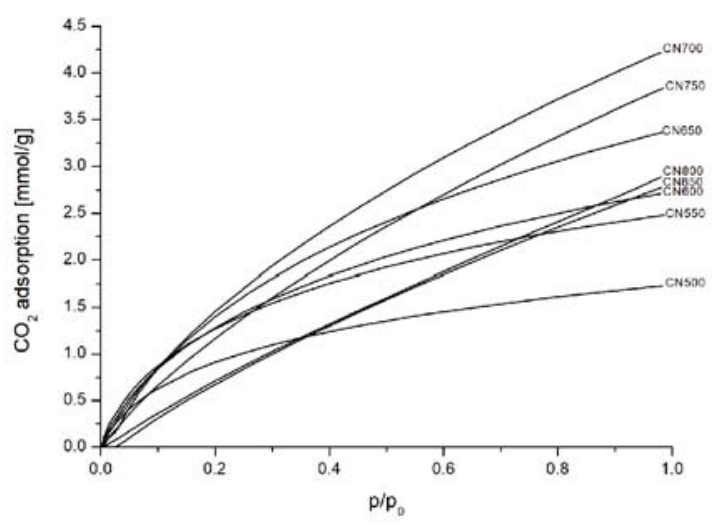

Figure 4. Carbon dioxide adsorption isotherms at $0^{\circ} \mathrm{C}$ for obtained ACs
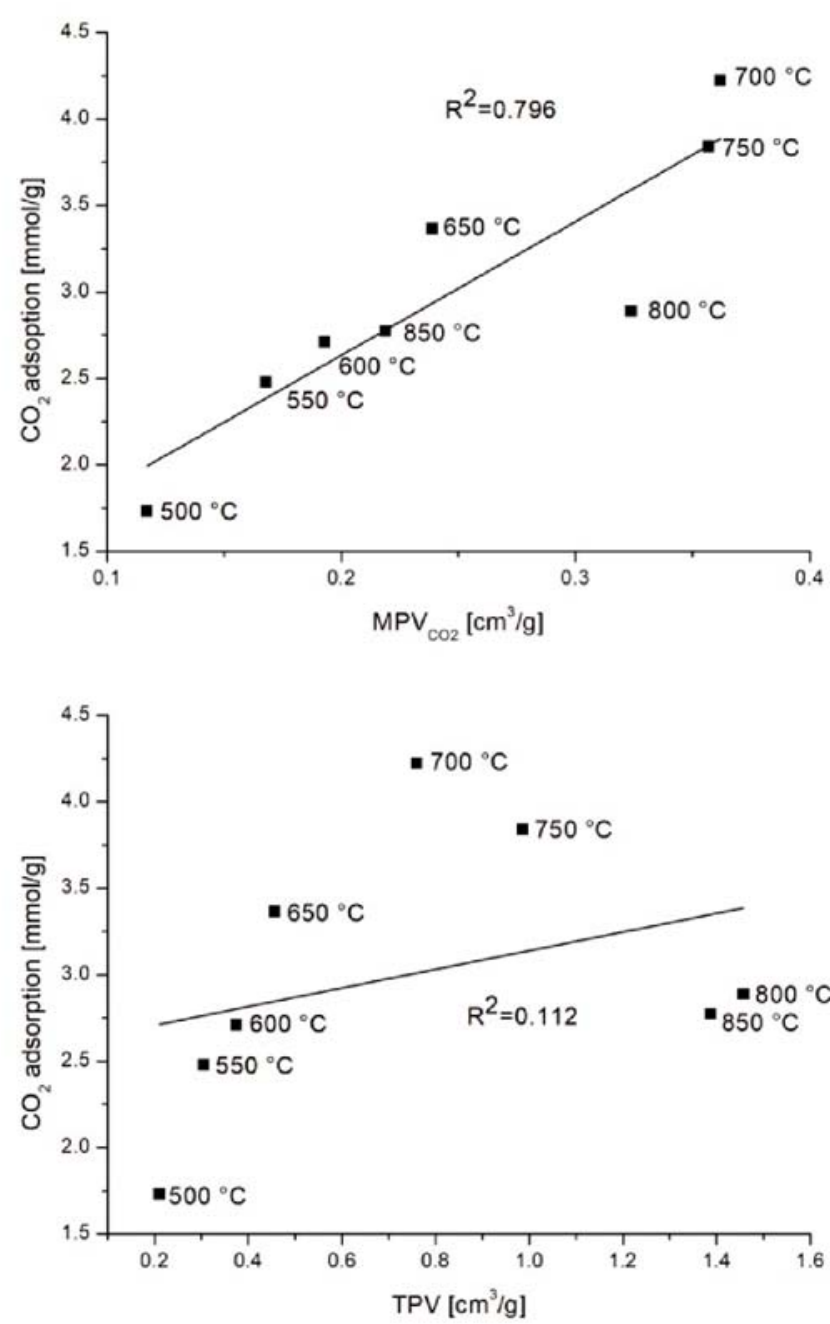

The relationship between volume of pores $\left(\mathrm{MPV}_{\mathrm{CO} 2}\right.$, $\mathrm{MPV}_{\mathrm{N} 2}$, and TPV) of the studied materials and the $\mathrm{CO}_{2}$ adsorption at $0^{\circ} \mathrm{C}$, are presented in Fig 5. exhibits. The coefficients of determination $\left(\mathrm{R}^{2}\right)$ for the $M P V_{N 2}$ and the $\mathrm{MPV}_{\mathrm{CO} 2}$ were high, and scatter for the TPV was significant. For that reason, we perceived that $\mathrm{CO}_{2}$ adsorption increased with $\mathrm{MPV}_{\mathrm{N} 2}$ and $\mathrm{MPV}_{\mathrm{CO} 2}$.

The effect of narrow micropore size distribution of activated carbons on $\mathrm{CO}_{2}$ adsorption at temperatures of $273 \mathrm{~K}$ was studied. The pore sizes in the range of $0.3-1.5$ $\mathrm{nm}$ were taken into consideration.

Fig. 6. demonstrates the relationship between the coefficient of determination $\left(\mathrm{R}^{2}\right)$ and micropore diameter. $\mathrm{R}^{2}$ initially fluctuate, then increase up to the micropores diameter of $0.82 \mathrm{~nm}$, and at the end decrease.

The dependence between the $\mathrm{CO}_{2}$ adsorption and the cumulative pore volume in pore size ranging from $0.31 \mathrm{~nm}$ to $0.82 \mathrm{~nm}$ is presented in Fig. 7. It was done to estimated the strict range of pore size for $\mathrm{CO}_{2}$ adsorption. The best linear relationship $\left(\mathrm{R}^{2}=0.97\right)$ was observed in the pore size range of $0.31-0.82 \mathrm{~nm}$. It can be inferred that the volume of micropores in this range was essential for the $\mathrm{CO}_{2}$ adsorption at $0^{\circ} \mathrm{C}$ and 1 bar. Congruent results were obtained by Presser et al. ${ }^{\mathbf{9 6}}$, Deng et al. ${ }^{97}$ and Serafin et al. ${ }^{49}$.

The SEM images in Figure 8. indicate that structures of activated carbons are unordered and had an irregular shape.

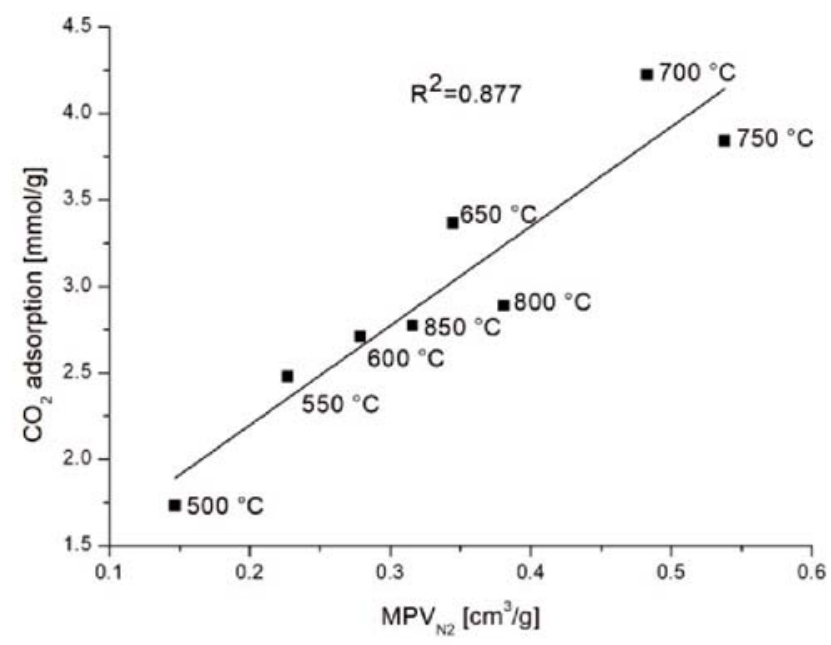

Figure 5. The dependence between volumes of pores $\left(\mathrm{MPV}_{\mathrm{CO} 2}, \mathrm{MPV}_{\mathrm{N} 2}\right.$ and $\mathrm{TPV}$ ) and the $\mathrm{CO} 2$ adsorption (at $0^{\circ} \mathrm{C}$ and 1 bar) 


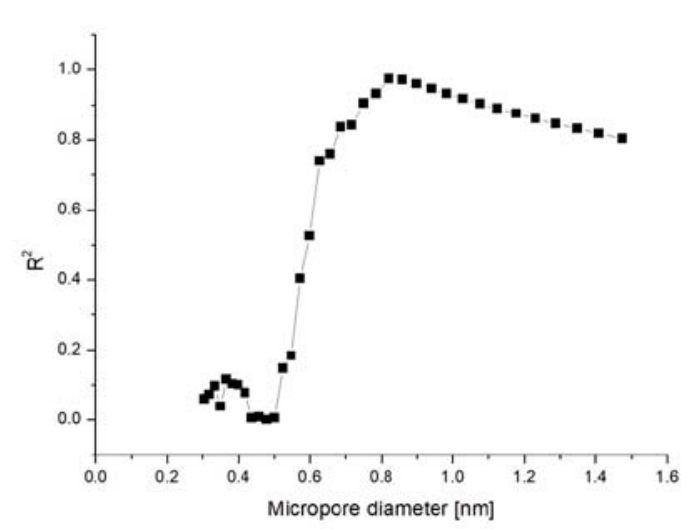

Figure 6. The dependence between $\mathrm{R}^{2}$ values and the micropore diameter at $0^{\circ} \mathrm{C}$ and 1 bar

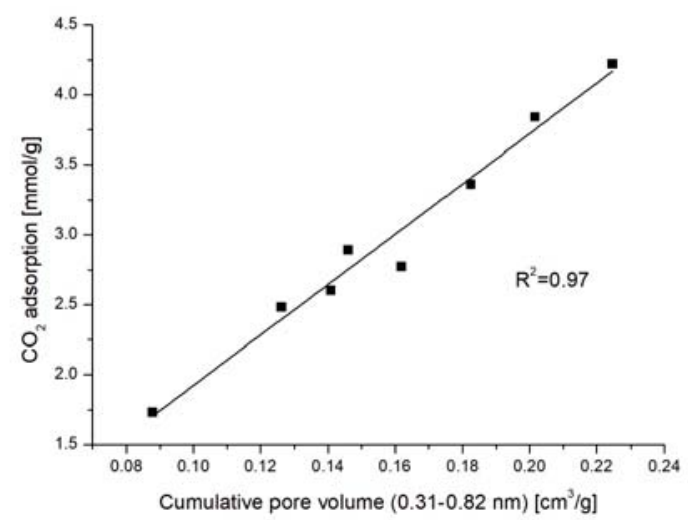

Figure 7. The best linear relationship between the cumulative pore volume in the range $0.31-0.82 \mathrm{~nm}$ and the $\mathrm{CO}_{2}$ adsorption at $0^{\circ} \mathrm{C}$ and 1 bar
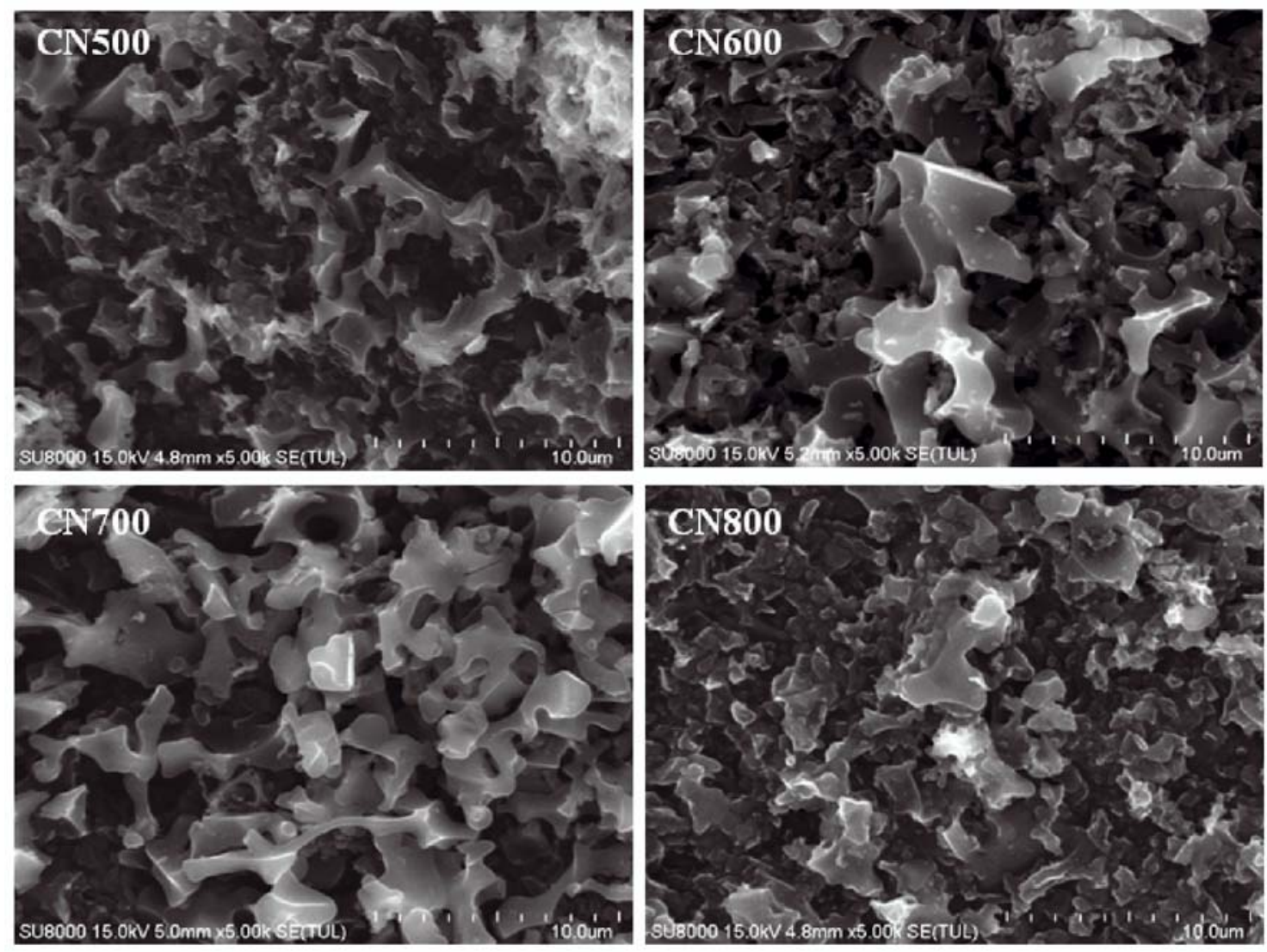

\section{Activated carbons obtained from common nettle} (Urtica dioica L.) by the chemical activation with $\mathrm{KOH}$ have a well-developed microporous structure. All the obtained materials revealed presence of pores with diameters range of $0.3-10 \mathrm{~nm}$, while pores with diameter in the range of $0.4-0.7 \mathrm{~nm}$ occupied the largest volume in all the materials. The pore volume gradually decreased with increasing of the pore diameter. It means that smaller pores are dominant in examined ACs. With the increase of the carbonization temperature up to $800^{\circ} \mathrm{C}$, the specific surface area and the total pore volume tended to increase. The volume of micropores also was increasing in materials prepared at temperatures up to $700^{\circ} \mathrm{C}$ for the $\mathrm{MPV}_{\mathrm{CO} 2}$ and $750^{\circ} \mathrm{C}$ for the $\mathrm{MPV}_{\mathrm{N} 2}$. The material prepared at $800{ }^{\circ} \mathrm{C}$ showed the highest value of the specific surface area. All the obtained activated carbons had demonstrated the ability to adsorb $\mathrm{CO}_{2}$. The highest $\mathrm{CO}_{2}$ adsorption demonstrated material carbonized at $700^{\circ} \mathrm{C}$ and further increase in the carbonization temperature caused decrease in $\mathrm{CO}_{2}$ uptake by the activated carbon. Such effect is probably related to the chemical structure of ACs surface. Surface functional groups, which are responsible for adsorption capacity, can be degraded under the influence of the higher temperature. The $\mathrm{CO}_{2}$ adsorption tended to increase with values of the $\mathrm{MPV}_{\mathrm{N} 2}$ and the $\mathrm{MPV}_{\mathrm{CO} 2}$. The best linear relationship $\left(\mathrm{R}^{2}=0.97\right)$ between the $\mathrm{CO}_{2}$ adsorption and the cumulative pore volume was observed in the pore size range of $0.31-0.82 \mathrm{~nm}$. It might be due that

Figure 8. Scanning electron micrographs of activated carbons carbonized at $500^{\circ} \mathrm{C}, 600^{\circ} \mathrm{C}, 700^{\circ} \mathrm{C}$ and $800^{\circ} \mathrm{C}$ 
the volume of micropores in this range was crucial for $\mathrm{CO}_{2}$ adsorption at $273 \mathrm{~K}$ and 1 bar.

\section{LITERATURE CITED}

1. Michalkiewicz, B., Sreńscek-Nazzal, J. \& Ziebro, J. (2009). Optimization of Synthesis Gas Formation in Methane Reforming with Carbon Dioxide. Catal. Lett. 129, 142-148. DOI: 10.1007/s10562-008-9797-6.

2. Michalkiewicz, B. \& Koren, Z.C. (2015). Zeolite membranes for hydrogen production from natural gas: state of the art. J. Porous Mat. 22, 635-646. DOI: 10.1007/s10934015-9936-6.

3. Michalkiewicz, B. (2006). Esterification of methane as the first stage in converting the natural gas to methanoll. Przem. Chem. 85, 620-623.

4. Michalkiewicz, B. \& Kałucki, K. (2002). Direct conversion of methane into methanol formaldehyde and organic acids. Przem. Chem. 81, 165-170.

5. Lubkowski, K., Arabczyk, W., Grzmil, B., Michalkiewicz, B. \& Pattek-Jańczyk, A. (2007). Passivation and oxidation of an ammonia iron catalyst. Appl. Catal., A. 329, 137-147. DOI: 10.1016/j.apcata.2007.07.006.

6. Michalkiewicz, B. \& Opaczewska, L. (2003). Novel condensed-phase catalysts for oxidation of methane. Przem. Chem. 82, 629-630.

7. Enger, B.C., Lødeng, R. \& Holmen, A. (2008). A review of catalytic partial oxidation of methane to synthesis gas with emphasis on reaction mechanisms over transition metal catalysts. Appl. Catal., A. 346, 1-27. DOI: 10.1016/j.apcata.2008.05.018.

8. Michalkiewicz, B., Sreńscek-Nazzal, J., Tabero, P., Grzmil, B. \& Narkiewicz, U. (2008). Selective methane oxidation to formaldehyde using polymorphic T-, M-, and $\mathrm{H}$-forms of niobium(V) oxide as catalysts. Chem. Pap. - Chem. Zvesti. 62, 106-113. DOI: 10.2478/s11696-007-0086-4.

9. Michalkiewicz, B. (2005). Kinetics of partial methane oxidation process over the Fe-ZSM-5 catalysts. Chem. Pap. Chem. Zvesti. 59, 403-408. DOI: 10.1016/j.apcata.2004.09.005.

10. Michalkiewicz, B. (2004). Partial oxidation of methane to formaldehyde and methanol using molecular oxygen over Fe-ZSM-5. Appl. Catal., A. 277, 147-153. DOI: 10.1016/j. apcata.2004.09.005.

11. Markowska, A. \& Michalkiewicz, B. (2009). Biosynthesis of methanol from methane by Methylosinus trichosporium OB3b. Chem. Pap. - Chem. Zvesti. 63, 105-110. DOI: 10.2478/ s11696-008-0100-5.

12. Michalkiewicz, B., Ziebro, J. \& Sreńscek-Nazzal, J. (2006). Direct oxidation of methane to formaldehyde. Przem. Chem. 85, 624-626.

13. Kałucki, K., Michalkiewicz, B., Morawski A.W., Arabczyk, W. \& Ziebro, J. (1995). Oxidation of methane to formaldehyde. Przem. Chem. 74, 135-136.

14. Galadim, A. \& Muraza, O. (2016). Revisiting the oxidative coupling of methane to ethylene in the golden period of shale gas: A review. J. Ind. Eng. Chem. 37, 1-13, DOI: 10.1016/j. jiec.2016.03.027.

15. Corredor, E.C., Chitta, P. \& Deo, M.D. (2019). Technoeconomic evaluation of a process for direct conversion of methane to aromatics. Fuel Process. Technol. 183, 55-61, DOI: 10.1016/j.fuproc.2018.05.038.

16. Michalkiewicz, B. (2011). Methane oxidation to methyl bisulfate in oleum at ambient pressure in the presence of iodine as a catalyst. Appl. Catal., A. 394, 266-268. DOI: 10.1016/j. apcata.2011.01.014.

17. Michalkiewicz, B. (2006). The kinetics of homogeneous catalytic methane oxidation. Appl. Catal., A. 307, 270-274. DOI: $10.1016 /$ j.apcata.2006.04.006.

18. Michalkiewicz, B. \& Kosowski, P. (2007). The selective catalytic oxidation of methane to methyl bisulfate at ambient pressure. Catal. Commun. 8, 1939-1942. DOI: 10.1016/j. catcom.2007.03.014.

19. Michalkiewicz, B., Jarosińska, M. \& Łukasiewicz, I. (2009). Kinetic study on catalytic methane esterification in oleum catalyzed by iodine. Chem. Eng. J. 154, 156-161. DOI: 10.1016/j.cej.2009.03.046.

20. Michalkiewicz, B. (2006). Methane esterification in oleum. Chem. Pap. - Chem. Zvesti. 60, 371-374. DOI: 10.2478/ s11696-006-0067-z.

21. Michalkiewicz, B. \& Balcer, S. (2012). Bromine catalyst for the methane to methyl bisulfate reaction. Pol. J. Chem. Technol. 14, 19-21. DOI: 10.2478/v10026-012-0096-z.

22. Jarosińska, M., Lubkowski, K., Sośnicki, J.G. \& Michalkiewicz, B. (2008). Application of Halogens as Catalysts of $\mathrm{CH}_{4}$ Esterification. Catal. Lett. 126, 407-412. DOI: 10.1007/ s10562-008-9645-8.

23. Michalkiewicz, B. \& Ziebro, J. (2004). Non-classical prospective methods of obtaining methanol and formaldehyde. Chem. Process. Eng-Inz. 25, 1973-1980.

24. Michalkiewicz, B., Kałucki, K. \& Sośnicki, J.G. (2003). Catalytic system containing metallic palladium in the process of methane partial oxidation. J. Catal. 215, 14-19. DOI: 10.1016/ S0021-9517(02)00088-X.

25. Michalkiewicz, B., Ziebro, J. \& Tomaszewska, M. (2006). Preliminary investigation of low pressure membrane distillation of methyl bisulphate from its solutions in fuming sulphuric acid combined with hydrolysis to methanol. J. Membr. Sci. 286, 223-227. DOI: 10.1016/j.memsci.2006.09.039.

26. Michalkiewicz, B. (2003). Methane conversion to methanol in condensed phase. Kinet. Catal. 44, 801-805. DOI: 10.1023/B:KICA.0000009057.79026.0b.

27. Michalkiewicz, B. (2008). Assessment of the possibility of the methane to methanol transformation. Pol. J. Chem. Technol. 10, 20-26. DOI: 10.2478/v10026-008-0023-5.

28. Michalkiewicz, B. (2003). Partial oxidation of methane to oxygenates. Przem. Chem. 82, 627-628.

29. Michalkiewicz, B. \& Majewska, J. (2014). Diametercontrolled carbon nanotubes and hydrogen production. Int. J. Hydrogen Energy 39, 4691-4697. DOI: 10.1016/j.ijhydene.2013.10.149.

30. Majewska, J. \& Michalkiewicz, B. (2016). Preparation of Carbon Nanomaterials over Ni/ZSM-5 Catalyst Using Simplex Method Algorithm. Acta Phys. Pol., A. 129, 153-157. DOI: 10.12693/APhysPolA.129.153.

31. Majewska, J. \& Michalkiewicz, B.(2013) Low temperature one-step synthesis of cobalt nanowires encapsulated in carbon. Appl. Phys. A: Mater. Sci. Process. 111, 1013-1016. DOI: 10.1007/ s00339-013-7698-z.

32. Ziebro, J., Skorupińska, B., Kądziołka, G. \& Michalkiewicz, B. (2013). Synthesizing Multi-walled Carbon Nanotubes over a Supported-nickel Catalyst. Fuller. Nanotub. Car. N. 21, 333-345. DOI: 10.1080/1536383X.2011.613543.

33. Majewska, J. \& Michalkiewicz, B. (2016). Production of hydrogen and carbon nanomaterials from methane using $\mathrm{Co} /$ ZSM-5 catalyst. Int. J. Hydrogen Energy 41, 8668-8678. DOI: 10.1016/j.ijhydene.2016.01.097.

34. Ziebro, J., Łukasiewicz, I., Borowiak-Palen, E. \& Michalkiewicz, B. (2010). Low temperature growth of carbon nanotubes from methane catalytic decomposition over nickel supported on a zeolite. Nanotechnology 21, 1-6. DOI: 10.1088/09574484/21/14/145308.

35. Majewska, J. \& Michalkiewicz, B. (2014). Carbon nanomaterials produced by the catalytic decomposition of methane over Ni/ZSM-5 Significance of Ni content and temperature. New Carbon Mater. 29, 102-108. DOI: 10.1016/ S1872-5805(14)60129-3.

36. Ziebro, J., Łukasiewicz, I., Grzmil, B., Borowiak-Palen, E. \& Michalkiewicz, B. (2009). Synthesis of nickel nanocapsules and carbon nanotubes via methane CVD. J. Alloys Compd. 485, 695-700. DOI: 10.1016/j.jallcom.2009.06.039. 
37. Lunsford, J.H. (2000). Catalytic conversion of methane to more useful chemicals and fuels: a challenge for the 21st century. Catal. Today. 63, 165-174. DOI: 10.1016/S0920-5861(00)00456-9.

38. Michalkiewicz, B., Majewska, J., Kądziołka, G., Bubacz, K., Mozia, S. \& Morawski, A. W. (2014). Reduction of $\mathrm{CO}_{2}$ by adsorption and reaction on surface of $\mathrm{TiO}_{2}$-nitrogen modified photocatalyst. $J$. $\mathrm{CO}_{2}$ Util. 5, 47-52. DOI: $10.1016 / \mathrm{j}$. jcou.2013.12.004.

39. Wałęsa-Chorab, M., Patroniak, V., Kubicki, M., Kądziołka, G., Przepiórski, J. \& Michalkiewicz, B. (2012). Synthesis, structure, and photocatalytic properties of new dinuclear helical complex of silver(I) ions. J. Catal. 291, 1-8. DOI: 10.1016/j. jcat.2012.03.025.

40. Marcinkowski, D., Wałęsa-Chorab, M., Patroniak, V., Kubicki, M., Kądziołka, G. \& Michalkiewicz, B. (2014). A new polymeric complex of silver(I) with a hybrid pyrazine-bipyridine ligand - synthesis, crystal structure and its photocatalytic activity. New J. Chem. 38, 604-610. DOI: 10.1039/c3nj01187a.

41. Marcinkowski, D., Wałęsa-Chorab, M., Kubicki, M., Hoffmann, M., Kądziołka, G., Michalkiewicz, B. \& Patroniak, V. (2015). A new 2,6-di(anthracen-9-yl)pyridine ligand and its complexes with $\mathrm{Ag}(\mathrm{I})$ ions: Synthesis, structure and photocatalytic activity. Polyhedron 90, 91-98. DOI: 10.1016/j. poly.2014.12.049.

42. Gray, M.L., Hoffman, J.S., Hreha, D.C., Fauth, D.J., Hedges, S.W., Champagne, K.J. \& Pennline, H.W. (2009). Parametric study of solid amine sorbents for the capture of carbon dioxide. Energy Fuels 23, 4840-4844. DOI:10.1021/ ef9001204.

43. Sayari, A., Belmabkhout, Y. \& Serna-Guerrero, R. (2011). Flue gastreatment via $\mathrm{CO}_{2}$ adsorption. Chem. Eng. J. 171, 760-774. DOI: 10.1016/j.cej.2011.02.007.

44. Młodzik, J., Sreńscek-Nazzal, J., Narkiewicz, U., Morawski, A.W., Wróbel, R.J. \& Michalkiewicz, B. (2016). Activated Carbons from Molasses as $\mathrm{CO}_{2}$ Sorbents. Acta Phys. Pol. A. 129, 402-404. DOI: 10.12693/APhysPolA.129.402.

45. Sreńscek-Nazzal, J., Narkiewicz, U., Morawski, A.W., Wróbel, R., Gęsikiewicz-Puchalska, A. \& Michalkiewicz, B. (2016). Modification of Commercial Activated Carbons for $\mathrm{CO}_{2}$ Adsorption. Acta Phys. Pol. A. 129, 394-401. DOI: 10.12693/ APhysPolA.129.394.

46. Gęsikiewicz-Puchalska, A., Zgrzebnicki, M., Michalkiewicz, B., Narkiewicz, U., Morawski, A. W. \& Wróbel, R. J. (2017). Improvement of $\mathrm{CO}_{2}$ uptake of activated carbons by treatment with mineral acids. Chem. Eng. J. 309, 159-171. DOI: 10.1016/j.cej.2016.10.005.

47. Glonek, K., Sreńscek-Nazzal, J., Narkiewicz, U., Morawski, A.W., Wróbel, R.J. \& Michalkiewicz, B. (2016). Preparation of Activated Carbon from Beet Molasses and $\mathrm{TiO}_{2}$ as the Adsorption of $\mathrm{CO}_{2}$. Acta Phys. Pol. A. 129, 158-161. DOI: 10.12693/APhysPolA.129.158.

48. Sreńscek-Nazzal, J., Narkiewicz, U., Morawski, A.W., Wróbel, R.J. \& Michalkiewicz, B. (2015). Comparison of Optimized Isotherm Models and Error Functions for Carbon Dioxide Adsorption on Activated Carbon. J. Chem. Eng. Data. 60, 3148-3158. DOI: 10.1021/acs.jced.5b00294.

49. Serafin, J., Narkiewicz, U., Morawski, A.W., Wróbel, R.J. \& Michalkiewicz, B. (2017). Highly microporous activated carbons from biomass for $\mathrm{CO}_{2}$ capture and effective micropores

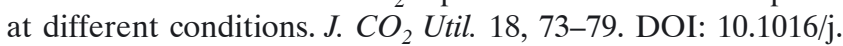
jcou.2017.01.006.

50. Lendzion-Bieluń, Z., Czekajło, Ł., Sibera, D., Moszyński, D., Sreńscek-Nazzal, J., Morawski, A.W., Wróbel, R.J., Michalkiewicz, B., Arabczyk, W. \& Narkiewicz, U. (2018). Surface characteristics of KOH-treated commercial carbons applied for $\mathrm{CO}_{2}$ adsorption. Adsorpt. Sci. Technol. 36, 478-492. DOI: $10.1177 / 0263617417704527$.

51. Zgrzebnicki, M., Krauze, N., Gęsikiewicz-Puchalska, A., Kapica-Kozar, J., Piróg, E., Jędrzejewska, A., Michalkiewicz, B., Narkiewicz, U., Morawski, A.W. \& Wróbel, R.J. (2017). Impact on $\mathrm{CO}_{2}$ Uptake of MWCNT after Acid Treatment Study. $J$. Nanomater., 1-11. DOI: 10.1155/2017/7359591.

52. Gong, J., Michalkiewicz, B., Chen, X., Mijowska, E., Liu, J., Jiang, Z., Wen, X. \& Tang, T. (2014). Sustainable Conversion of Mixed Plastics into Porous Carbon Nanosheets with High Performances in Uptake of Carbon Dioxide and Storage of Hydrogen. ASC Sustain. Chem. Eng. 2, 2837-2844. DOI: $10.1021 / \mathrm{sc} 500603 \mathrm{~h}$.

53. Choma, J., Osuchowski, Ł., Marszewski, M., Dziura, A. \& Jaroniec, M. (2016). Developing microporosity in Kevlar1derived carbon fibers by $\mathrm{CO}_{2}$ activation for $\mathrm{CO}_{2}$ adsorption. J.CO Util. 16, 17-22. DOI: 10.1016/j.jcou.2016.05.004.

54. Marszewska, J. \& Jaroniec, M. (2017). Tailoring porosity in carbon spheres for fast carbon dioxide adsorption. J. Colloid Interface Sci. 487, 162-174. DOI: 10.1016/j.jcis.2016.10.033.

55. Harlick, P.J.E. \& Tezel, F.H. (2004). An experimental adsorbent screening study for $\mathrm{CO}_{2}$ removal from $\mathrm{N}_{2}$. Micropor. Mesopor. Mat. 76, 71-79. DOI: 10.1016/j.micromeso.2004.07.035.

56. Walton, K.S., Abney, M.B. \& LeVan, D.M. (2006). $\mathrm{CO}_{2}$ adsorption in $\mathrm{Y}$ and $\mathrm{X}$ zeolites modified by alkali metal cation exchange. Micropor. Mesopor. Mat. 91, 78-84. DOI: 10.1016/j. micromeso.2005.11.023.

57. Millward, A.R. \& Yaghi, O.M. (2005). Metal-organic frameworks with exceptionally high capacity for storage of carbon dioxide at room temperature. J. Am. Chem. Soc. 127, 17998-17999. DOI: 10.1021/ja0570032.

58. Cheng, Y., Rondo, A., Noguchi, H., Kajiro, H., Urita, K., Ohba, T., Kaneko, K. \& Kanoh, H. (2009). Reversible structural change of $\mathrm{Cu}-\mathrm{MOF}$ on exposure to water and its $\mathrm{CO}_{2}$ adsorptivity. Langmuir 25, 4510-4513. DOI: 10.1021/la803818p.

59. Kapica-Kozar, J., Piróg, E., Kusiak-Nejman, E., Wróbel, R.J., Gęsikiewicz-Puchalska, A., Morawski, A.W., Narkiewicz, U. \& Michalkiewicz, B. (2017). Titanium dioxide modified with various amines used as sorbents of carbon dioxide. New J. Chem. 41, 1549-1557. DOI: 10.1039/c6nj02808j.

60. Kapica-Kozar, J., Piróg, E., Wróbel, R.J., Mozia, S., Kusiak-Nejman, E., Morawski, A.W., Narkiewicz, U. \& Michalkiewicz, B. (2016). $\mathrm{TiO}_{2} /$ titanate composite nanorod obtained from various alkali solutions as $\mathrm{CO}_{2}$ sorbents from exhaust gases. Micropor. Mesopor. Mat. 231, 117-127. DOI: 10.1016/j.micromeso.2016.05.024.

61. Kapica-Kozar, J., Michalkiewicz, B., Wróbel, R.J., Mozia, S., Piróg, E., Kusiak-Nejman, E., Serafin, J., Morawski, A.W. \& Narkiewicz, U. (2017). Adsorption of carbon dioxide on TEPA-modified $\mathrm{TiO}_{2} /$ titanate composite nanorods. New J. Chem. 41, 7870-7885. DOI: 10.1039/c7nj01549f.

62. Yu-Dong D., Gan S., Qiang L., Xun Z. \& Rong C. (2016). Bench scale study of $\mathrm{CO}_{2}$ adsorption performance of $\mathrm{MgO}$ in the presence of water vapour, Energy 112, 101-110. DOI: 10.1016/j.energy.2016.06.064.

63. Ferreira, D., Magalhaes, R., Taveira, P. \& Mendes, A. (2011). Effective adsorption equilibrium isotherms and breakthroughs of water vapor and carbon dioxide on different adsorbents. Ind. Eng. Chem. Res. 50, 10201-10210. DOI: 10.1021/ie2005302.

64. Samanta, A., Zhao, A., Shimizu, G.K.H., Sarkar, P. \& Gupta, R. (2012). Post-combustion $\mathrm{CO}_{2}$ capture using solid sorbents: A review. Ind. Eng. Chem. Res. 51, 1438-1463. DOI: 10.1021/ie200686q.

65. Kwiatkowski, M. \& Broniek, E. (2013). Application of the LBET class adsorption models to the analysis of microporous structure of the active carbons produced from biomass by chemical activation with the use of potassium carbonate. Colloids Surf., A. 427, 47-52. DOI: 10.1016/j.colsurfa.2013.03.002.

66. Kwiatkowski, M. (2008). Employing the new computer LBET class models with multivariant fitting to the analysis of single and double adsorption isotherms generated by the selected classical equations in different relative pressures. $J$. Math. Chem. 42, 815-835. DOI: 10.1007/s10910-006-9143-4. 
67. Kwiatkowski, M. (2007). Comparison of the evaluation reliability of microporous structure parameters by employing single and double adsorption isotherms. Colloids Surf., A. 294, 92-101. DOI: 10.1016/j.colsurfa.2006.07.050.

68. Kwiatkowski, M. (2009). Computer analysis of the microporous structure of activated carbon fibres using the fast multivariant identification procedure of adsorption system parameters. Colloids Surf., A. 330, 266-275. DOI: 10.1007/ s00894-007-0260-1.

69. Sreńscek-Nazzal, J. \& Michalkiewicz, B. (2011) The simplex optimization for high porous carbons preparation. Pol. J. Chem. Technol. 13, 63-70. DOI: 10.2478/v10026-011-0051-4.

70. Kwiatkowski, M., Sreńscek-Nazzal, J. \& Michalkiewicz, B. (2017) An analysis of the effect of the additional activation process on the formation of the porous structure and pore size distribution of the commercial activated carbon WG-12. Adsorption. 23, 551-561. DOI: 10.1007/s10450-017-9867-4.

71. Sreńscek-Nazzal, J., Kamińska, W., Michalkiewicz, B. \& Koren, Z.C. (2013). Production, characterization and methane storage potential of $\mathrm{KOH}$-activated carbon from sugarcane molasses. Ind. Crop. Prod. 47, 153-159. DOI: 10.1016/j. indcrop.2013.03.004.

72. Kwiatkowski, M. (2013). Methane storage in carbonaceous porous materials. Przem. Chem. 92, 629-633.

73. Kwiatkowski, M. \& Duda, J.T. (2014). Fast multivariant analysis of the adsorption isotherm of the carbon dioxide and methane. Przem. Chem. 93, 878-881.

74. Wenelska, K., Michalkiewicz, B., Chen, X. \& Mijowska, E. (2014). Pd nanoparticles with tunable diameter deposited on carbon nanotubes with enhanced hydrogen storage capacity. Energy 75, 549-554. DOI: 10.1016/j.energy.2014.08.016.

75. Wenelska, K., Michalkiewicz, B., Gong, J., Tang, T., Kaleńczuk, R., Chen, X. \& Mijowska, E. (2013). In situ deposition of Pd nanoparticles with controllable diameters in hollow carbon spheres for hydrogen storage. Int. J. Of Hydrogen Energy 38, 16179-16184. DOI: 10.1016/j.ijhydene.2013.10.008.

76. Zielińska, B., Michalkiewicz, B., Chen, X., Mijowska, E. \& Kaleńczuk, R.J. (2016). Pd supported ordered mesoporous hollow carbon spheres (OMHCS) for hydrogen storage. Chem. Phys. Lett. 647, 14-19. DOI: 10.1016/j.cplett.2016.01.036.

77. Zielińska, B., Michalkiewicz, B., Mijowska, E. \& Kaleńczuk, R.J. (2015). Advances in Pd Nanoparticle Size Decoration of Mesoporous Carbon Spheres for Energy Application. $\mathrm{Na}$ noscale Res. Lett. 10, 1-7. DOI: 10.1186/s11671-015-1113-y.

78. Baca, M., Cendrowski, K., Banach, P., Michalkiewicz, B., Mijowska, E., Kaleńczuk, R.J. \& Zielińska, B. (2017). Effect of Pd loading on hydrogen storage properties of disordered mesoporous hollow carbon spheres. Int. J. Hydrogen Energy 42, 30461-30469. DOI: 10.1016/j.ijhydene.2017.10.146.

79. Baca, M., Cendrowski, K., Kukułka, W., Bazarko, G., Moszyński, D., Michalkiewicz, B., Kaleńczuk, R.J. \& Zielińska, B. (2018). A Comparison of Hydrogen Storage in Pt, Pd and $\mathrm{Pt} / \mathrm{Pd}$ Alloys Loaded Disordered Mesoporous Hollow Carbon Spheres. Nanomaterials 8, 1-13. DOI: 10.3390/nano8090639.

80. Glonek, K., Wróblewska, A., Makuch, E., Ulejczyk, B., Krawczyk, K., Wróbel, R.J., Koren, Z.C. \& Michalkiewicz, B. (2017). Oxidation of limonene using activated carbon modified in dielectric barrier discharge plasma. Appl. Surf. Sci. 420, 873-881. DOI: 10.1016/j.apsusc.2017.05.136.

81. Wróblewska, A., Miądlicki, P., Sreńscek-Nazzal, J., Sadłowski, M., Koren, Z.C. \& Michalkiewicz, B. (2018). Alphapinene isomerization over Ti-SBA- 15 catalysts obtained by the direct method: The influence of titanium content, temperature, catalyst amount and reaction time. Micropor. Mesopor. Mat. 258, 72-82. DOI: 10.1016/j.micromeso.2017.09.007.

82. Malko, M., Antosik, A.K., Wróblewska, A., Czech, Z., Wilpiszewska, K., Miądlicki, P. \& Michalkiewicz, B. (2017). Montmorillonite as the catalyst in oxidation of limonene with hydrogen peroxide and in isomerization of limonene. Pol. J. Chem. Technol. 19, 50-58. DOI: 10.1515/pjct-2017-0067.
83. Wróblewska, A., Makuch, E., Młodzik, J., Koren, Z.C. \& Michalkiewicz, B. (2017). Fe/Nanoporous Carbon Catalysts Obtained from Molasses for the Limonene Oxidation Process. Catal. Lett. 147, 150-160. DOI: 10.1007/s10562-016-1910-7.

84. Młodzik, J., Wróblewska, A., Makuch, E., Wróbel, R.J. \& Michalkiewicz, B. (2016). Fe/EuroPh catalysts for limonene oxidation to 1,2-epoxylimonene, its diol, carveol, carvone and perillyl alcohol. Catal. Today 268, 111-120. DOI: 10.1016/j. cattod.2015.11.010.

85. Wróblewska, A., Makuch, E., Młodzik, J. \& Michalkiewicz, B. (2017). Fe-carbon nanoreactors obtained from molasses as efficient catalysts for limonene oxidation. Green Process. Synth. 6, 397-401. DOI: 10.1515/gps-2016-0148.

86. Yahya, M.A., Al-Qodah, Z. \& Ngah, C.W.Z. (2015). Agricultural bio-waste materials as potential sustainable precursors used for activated carbon production: A review. Renew. Sust. Energ. Rev. 46, 218-235.

87. Grycova, B., Koutnik, I. \& Pryszcz, A. (2016). Pyrolysisprocess for the treatment of food waste. Bioresource Technol. 218, 1203-1207. DOI:10.1016/j.biortech.2016.07.064

88. Lestinsky, P., Grycova, B., Pryszcz, A., Martaus, A. \& Matejova, L. (2017). Hydrogen production from microwave catalytic pyrolysis of spruce sawdust. J. Anal. Appl. Pyrol. 124, 175-179. DOI:10.1016/j.jaap.2017.02.008.

89. Grycova, B., Koutnik, I, Pryszcz, A. \& Kaloc, M. (2016). Application of pyrolysis process in processing of mixed food wastes. Pol. J. Chem. Technol. 18, 19-23. DOI:10.1515/pjct2016-0004.

90. Grycova, B., Pryszcz, A., Lestinsky, P. \& Chamradova, K. (2017). Preparation and characterization of sorbents from food waste. Green Process. Synth. 6, 287-293. DOI:10.1515/ gps-2016-0182.

91. Grycova, B., Pryszcz, A., Lestinsky, P. \& Chamradova, K. (2018). Influence of potassium hydroxide and method of carbonization treatment in garden and corn waste microwave pyrolysis. Biomass Bioenerg. 118, 40-45. DOI:10.1016/j. biombioe.2018.07.022.

92. Hernandez, J.R., Aquino F.L., Capareda, S.C. (2007). Activated carbon production from pyrolysis and steam activation of cotton gin trash. Am. Soc. Agric. Biol. Eng., 1-8.

93. Thommes, M., Kaneko, K., Neimark, A.V., Olivier, J.P., Rodriguez-Reinoso, F., Rouquerol, J. \& Sing, K.S.W. (2015). Physisorption of gases, with special reference to the evaluation of surface area and pore size distribution (IUPAC Technical Report). Pure Appl. Chem. 87, 1051-1069. DOI: 10.1515/pac2014-1117.

94. Sing, K.S.W. \& Williams, R.T. (2004) Physisorption Hysteresis Loops and the Characterization of Nanoporous Materials. Adsorpt. Sci. Technol. 22, 773-782. DOI: 10.1260/0263617053499032.

95. Jagiello, J. \& Thommes, M. (2004). Comparison of DFT characterization methods based on $\mathrm{N}_{2}, \mathrm{Ar}, \mathrm{CO}_{2}$, and $\mathrm{H}_{2}$ adsorption applied to carbons with various pore size distributions. Carbon 42, 1227-1232. DOI: 10.1016/j. carbon.2004.01.022.

96. Presser, V., McDonough, J., Yeon S.H. \& Gogotsi Y. (2011). Effect of pore size on carbon dioxide sorption by carbide derived carbon. Energy Environ. Sci. 4, 3059-3066. DOI: 10.1039/C1EE01176F.

97. Deng, S., Wei, H., Chen, T., Wang, B., Huang, J. \& Yu, G. (2014). Superior $\mathrm{CO}_{2}$ adsorption on pine nut shell-derived activated carbons and the effective micropores at different temperatures,. Chem. Eng. J. 253, 46-54. DOI: 10.1016/j. cej.2014.04.115. 